REPERTORIO BIBLIOGRÁFICO SOBRE DERECHOS HUMANOS

\author{
ANA POYAL COSTA \\ Facultad de Políticas y Sociologia \\ UNED
}


SUMARIO

I. Proteccion de los derechos humanos.-II. Eficacia De los DERECHOS HUMANOS A NIVEL INDIVIDUAL Y FRENTE A TERCEROS. 
Revista de Derecho Político, núm. 34, 1991, pp. 283-325

\title{
REPERTORIO BIBLIOGRÁFICO SOBRE DERECHOS HUMANOS
}

\author{
POR \\ ANA POYAL COSTA
}

Facultad de Políticas y Sociología

UNED

I. PROTECCIÓN DE LOS DERECHOS HUMANOS

AA. VV.: El Tribunal Constitucional (3 vols.), Dirección General de lo Contencioso, Instituto de Estudios Fiscales, Madrid 1981.

-: "Derechos Humanos y Constitución española», en Revista de la Facultad de Derecho de la Universidad Complutense, diciembre 1979.

-: Los Tribunales europeos constitucionales y los derechos fundamentales, CEC, Madrid 1984.

AGUIAR, L.: «Dogmática y teoría jurídica de los derechos fundamentales en la interpretación de éstos por el Tribunal Constitucional español», en Rev. UNED, n. ${ }^{\circ} 1919,1982$.

alcala-Zamora Castillo, N.: La protección procesal internacional de los derechos humanos, Civitas, Madrid 1975.

ALEXIDZE, L. A.: «Legal Nature of Jus cogens in contemporary International Law», RCADI, vol. 172, III, 1981.

ALKEMA, E. A.: Somme suggestions to improve the procedures of the ECHR pending the Court and the Commission, in Second Seminar on Internacional Law and European Law, Neuchâtel, marzo 1986. 
Almagro Nosete, J.: Garantia jurisdiccional de los derechos fundamentales, CEU, Madrid 1971.

ARCHER, A.: «Action by Unofficial Organizations on Human Rights", in The International Protection of Human Rights, E. Luard (Ed.), New York, Praeger, 1967.

Bacigalupo, E.: “Colisión de derechos fundamentales y justificación en el delito de injuria”, Revista de Derecho Constitucional, n. ${ }^{\circ} 20$, año 1987.

Bandrés Sánchez-Cruzart, J.: El Tribunal Europeo de los Derechos del Hombre, Ed. Bosch, Barcelona 1983.

BaRtolomeI, D. M.: La protezione dei diritti umani nell'ordinamento internazionale, Rome, Soc. ed. del Foro italiano, 1958.

BEDdARD, B.: «The Status of the European Convention on Human Rights in domestic law», International and comparative Law Quartely, 1967.

-: Human rights and Europe: a study of the machinery of Human Rights protection of the Council of Europe, Sweet and Maxwell, 1973 2nd, 1980.

BERgER, V.: «La Cour Européenne des Droits de l'Homme Réunion d'information sur la Convention Européenne des Droits de l'Homme», $B u$ lletin de la.Fédération Suisse des Avocats, Laussanne 1982.

BiscotTINI, G.: La convenzione Europea dei Diritti dell'Uomo nell'aplicazione Giurisprudenziale in Italia. Editore Dott. A Giuffré Editore, Milán 1981.

BISSELL, J.: «Negotiations by International Bodies and the Protection of Human Rights", Columbia Journal of Transnational Law, vol. 7, 1968.

Bissel, T. G.: «The International Committee of the Red Cross and the protection of human rights", Revue des Droits de I'Homme/Human rights journal (Paris), vol. I, n. ${ }^{\circ}$ 2, 1968.

Bоввıо, N.: «ll preambolo della Convenzione Europea dei Diritti dell'Uomo», Rivista di Diritti Internazionale, vol. 57, 1974.

Boletín de Jurisprudencia: Tribunal Europeo de Derechos Humanos: 25 años de jurisprudencia, 1959-1983. Publicaciones de las Cortes Generales, Madrid 1985.

Brown, L. N.: «Observations on the proposed accesion by the European Community to the European Convention on Human Rights", American Journal of Comparative Law, 1981, n. 4.

Buergenthal, T.: The American Convention of Human Rights: and illusion of progress", Miscellanea W. J. Ganshof van der Meersch, vol. 1, Brussels, Bruylant, 1972. 
BUERGENTHAL, T.: "The revised OAS charter and the protection of human rights", American Journal of International Law (Washington, D.C.), vol. 69, 1975.

-: «Nuevo examen de la aplicación del Convenio Europeo de Derechos Humanos en el orden jurídico interno", Revista de la Comisión Internacional de Juristas, vol. VII, n. ${ }^{\circ} 1,1966$.

-: «The domestic status of the European Convention on Human Rights», Buffalo Law Review, vol. XIII, 1963/64.

-: "The European Convention and its nation application: interaction of national law and modern international agreement some introductory observations", The American Journal of Comparative Law, vol. 18, n. $.^{\circ} 2,1970$.

BUERGENTHAL, T., y otros: La protección internacional de los derechos humanos en las Américas, Ed. Juricentro, Costa Rica 1983.

BurgoA, I.: Las garantias individuales, Ed. Porrúa, México 1970.

BRUNET, R.: La garantie internationale des droits de l'homme d'après la Charte de San Francisco, Genéve, C. Grasset, 1947.

Cabranes, J. A.: «Human rights and non-intervention in the inter-american system», Michigan Law Review (Ann. Arbor, Mich.), vol. 65, april 1967.

-: "The protection of human rights by the Organization of American States", American Journal of International Law (Washington, D.C.), vol. 62, n. ${ }^{\circ} 4,1965$.

Camargo, P. P.: "The American Convention on Human Rights", Revue des Droits de l'Homme/Human rights journal (París), vol. III, n. ${ }^{\circ}$ 2, 1970.

-: "L'amparo au Méxique et en Amérique Latine comme instrument de protection des droits de I'homme, Revue des Droits de l'Hommel Human'rights journal (Paris), vol. I, n. ${ }^{\circ} 3,1968$.

-: Problemática mundial de los derechos humanos y la democracia en América: los derechos humanos y el Derecho Internacional. México, Edit. Excelsior, 1960.

-: "The right to judicial protection: "amparo" and other Latin American remedies for the protection of human rights", Lawyers of the America (Coral Gables, Fla.), vol. 2, n. ${ }^{\circ} 2,1971$.

Camino, H.: La Convención Europea para la salvaguardia de los Derechos Humanos. Resultado de una experiencia internacional. Conferencia pronunciada en el Instituto Naval de Conferencias. Edición del Instituto de Publicaciones Navales, Buenos Aires, 29 de abril de 1968, publicada en 1970. 
CAmpinos, J.: Direito Internacional dos Direitos do-Homen. Editora Coimbra 1984.

Cancado Trindade, A. A.: «Exhaustion of local Remedies in the Jurisprudence of the European Court of Human Rights, An Appraisal», Revue des Droits de l'Homme, vol. 10, 1977.

-: Aplication of the rule of exhaustion of local remedies in international law. Its rationale in the international protection of individual rights. Cambridge University Press, 1983.

Cano MatA, A.: «El recurso de amparo. Doctrina del Tribunal Constitucional», Revista de Derecho Privado, Madrid 1983.

CAPotortI, F.: «The international measures of implementation included in the Covenants on Human Rights", in EIDE and SHOU, Proceedings of the Seventh Nobel Symposium (Oslo, september 25-27, 1967), Stockholm 1968.

-: Possibilities of the conflict in national legal systems betwen the European Convention and other international agreements. Human Rights in national and international law, the proceedings of the 2nd international Conference on the European Convention on Human Rights held in Vienna, 18-20 it 1965. Dobbs Ferry, N.Y. Oceana Publ., Manchester Univ. Press, 1968.

-: "Contributo allo studio della Convenzione Europea dei Diritti dell'Uomo", Rivista di Diritto Internazionale, n. ${ }^{\circ} 3,1974$.

CAREY, J.: International protection of human rights. Dobbs Ferry, N.Y., Oceana, 1968.

-: «Procedures for international protection of human rights", lowa Law Review (lowa City, lowa), vol. 53, october, 1967.

Carrillo Salcedo, J. A.: «La protección de los derechos humanos en las Comunidades Europeas", en Tratado de Derecho Comunitario Europeo, vol. II, dirigido por los Profesores Garcia de Enterría, González Campos y Muñoz Machado, Editorial Civitas, S. A., Madrid 1986.

-: The European Systems of Protection of Human Rights. Lecture in the International Institute of Human Rights-Sixteenth Study Session, Estrasburgo, julio 1985. 
CarRillo Salcedo, J. A.: El sistema jurisdiccional europeo de protección de los derechos humanos: La Comisión y el Tribunal Europeo de Derechos Humanos, en Jornadas sobre Derechos Humanos, Consejo General del Poder Judicial, Madrid, abril 1986.

Cassin, R.: La Cour Européenne des Droits de l'Homme. Annuaire européen, vol. 7, 1959-60.

Castberg, F.: La Convention Européenne des Droits de l'Homme et l'idée de justice. Mélanges René Cassing, vol. I, Pedone, Paris 1969.

-: Le droit de requete individuelle d'après la Convention Européenne des Droits de l'Homme. Multitudo legun ius Unmu, vol. I, 1973.

Castro CID, B. de: El reconocimiento de los Derechos Humanos, Tecnos, Madrid 1980.

Castro-Rial Garrone, F.: La protección individual y el derecho de reparación en el Convenio Europeo de Derechos Humanos, Editorial de la Universidad Complutense, 2 tomos, Madrid 1985.

CATALDI, G.: "La clausola di deroga della Convenzione Europea dei Diritti dell'Uomo", Rivista di Diritto Europeo, año 23,1983 , n. ${ }^{\circ} 1$.

Cerexhe, E.: «La protection des droits fondamentaux dans les Communautés Européennes", Revue Juridique et Politique. Independance et coopération, tomo $36, \mathrm{n} .{ }^{\circ} 1,1986$.

Chrysostomides, K.: "Competence" and "Incompatibility" in the Jurisprudence of the European Commission of Human Rights", Zao Revue, vol. 33, 1973.

Chueca Sancho, A. G.: «Los derechos humanos protegidos en la Convención americana de San José de 1969", Revista Española de Derecho Internacional, vol. 32, 1980.

Chueca Santos, A.: «No discriminación en la Convención Europea de Derechos Humanos", Revista de Instituciones Europeas, vol. 6, 1979.

Coblentz, W. K., y WARShaw, R. S.: «The European Convention for the Protection of Human Rights and Fundamental Freedoms", Law Review, California 1965. 
Cohen-Jonathan, G.: «Droits de l'Homme et pluralité des systèmes européens de protection internationale», en Human Rights Journal, vol. V, 1973.

-: «Cour Européenne des Droits de l'Homme, Chronique de Jurisprudence, 1978», Cahiers Droit Européen, n. ${ }^{\circ} 4,1979$.

--: "L'incidence de la Convention Européenne des Droits de l'Homme sur les Communautés Européennes», Annuaire européen, vol. 29, 1981, pp. 79-113. Nijhoff, La Haya 1983.

-: “Convention Européenne des Droits de l'Homme et Droits communautaires: une coordination nécessaire", Revue des Droits de I'Homme, vol. 5, n. $^{\circ} 4,1973$.

COHEN-JonAthan, G., y Jacque, J. P.: “Activité de la Commission Européenne des Droits de l'Homme», Annuaire Français de Droit International, 1979.

COMBACAU, J.: Obligations de résultat et obligations de comportement: Quelques questions et pas de réponse. Mélanges offerts a Paul Reuter, Ed. A. Pedone, Paris 1981.

CoRRIENTE CORdoBA, J. A.: «España y los convenios internacionales de protección de los derechos humanos", Anuario de Derecho Internacional, vol. III, 1976.

COUNCIL OF. EUROPE: Digest of Strasbourg Case-Law to the European Convention on Human Rights. Estrasburgo 1958.

—: La Convention Européenne des Droits de l'Homme. Estrasburgo 1958.

Coussirat-Coustere, V.: «La réserve française à l'article 15 de la Convention Européenne des Droits de l'Homme», Journal de Droit International, vol. 102, 1975.

CuAdRA, H.: La proyección internacional de los Derechos Humanos, UNAM, Instituto de Investigaciones Jurídicas, México 1970.

DAS, K.: «Measures of implementation of the International convention on the Elimination of All Forms of Racial Discrimination with special reference to the provisions concerning reports from States parties to the convention", Revue des Droits de l'HommelHuman rights journal (Paris), vol. IV, n. $2-3,1971$. 
DAUBIE, Ch.: «Communication sur le sujet de l'autorité des arrêts et des décisions des organes de la Convention Européenne des Droits de l'Homme", Revue des Droits de l'Homme, vol. VI, n. ${ }^{\circ}$ 3-4, 1973.

-: "Conciliation et protection européenne des droits de l'homme», Revue Belge de Droit International, vol. IX, n. ${ }^{\circ} 2,1973$.

-: L'autorité des Arrêts de la Cour Européenne des Droits de l'Homme: les problèmes soulevés par leur exécution. Mimeo; 1972.

-: "Vingt ans de protection européenne des droits de l'homme», Revue Générale Belge, 1971.

DAUSES, M. A.: "La protection des droits fondamentaux dans l'ordre juridique communautaire", Revue Trimestrielle de Droit Européen, 1984.

DeCleva, M.: "Le Convenzione europee e rapporti con il Conziglio d'Europa", Rivista di Diritto Europeo, 1962.

DEL Bo, D.: L'Eguaglianza nello stato contemporáneo, Milano 1950.

Demiche, A.: La Conception des libertés politiques dans la Convention Européenne des Droits de l'Homme. La Protection Internationale des droits de l'Homme. Presse Universitaire de Lyon 1981.

Demoura, D. L.: La Commission Européenne des Droits de l'Homme. Plénaire à l'Institut des Hautes Études Internationales de l'Université de Paris 1958.

DieZ DE VELASCo, M.: «Los derechos humanos y su garantía en el área del Consejo de Europa", Cuadernos para el Diálogo, n. ${ }^{\circ}$ XXIV, febrero de 1971.

-: Mecanismos de garantía y medios procesales de protección creados por la Convención Europea de los Derechos del Hombre. Homenaje a D. Nicolás Pérez Serrano. Madrid, tomo II, 1959.

DIJK, P. VAN, y HOOF, G. J. H. VAN: Theory and Practice of the European Convention on Human Rights. Kluwer law and Taxation Publishers, Netherlands 1976.

Dominiez, $\mathrm{CH}_{\text {H.: }}$ «La Convention Européenne des Droits de l'Homme devant le juge international», Schweizerisches Jahrbuch für Internationales Recht, vol. 28, 1972. 
Domínguez MARTín, S.: «El recurso de amparo y el Tribunal Constitucional», Boletín de Información del Ministerio de Justicia, n. ${ }^{\circ}$ 1.151, 1978.

Drzemczewski, A.: The European Human Rights Convention, articles 28 and 54. Topical Law. The Polythecnic of North London, Dep. of Law, vol. 4, 1982.

-: "The sui generis nature of the European Convention on Human Rights", The International and Comparative Law Quartely, 1980.

-: "A Constitutional Court for Europe», The Law Society's Gazette, 30-IV86.

-: «Fundamental rights and the European Communities: recent developments», The Human Rights Review, 2, 69-70, 1977.

Dunshee de Abranches, C. A.: Proteçao internacional dos direitos humanos. Río de Janeiro, Freitas Bastos, 1964.

DupuY, R. J.: «La Commission Européenne des Droits de l'Homme», Annuaire Française de Droit Internacional, 1957.

Ehlermann, C. D.: La Communauté Européenne et le système de protection de la Convention des Droits de l'Homme. La Protection Internationale des Droits de I'Homme. Presses Universitaires de Lyon, 1982.

EIDE, A., y SHOV, A. (Eds.): International Protection of Human Rights. Proceedings of the Seventh Nobel Symposium. Oslo, 25-27 september 1967, Almquist and Wiksell, 1968.

EISSEN, M. A.: «Communication sur le sujet de l'autorité des arrêts et les décisions des organes de la Convention Européenne de l'Homme", Revue des Droits de l'Homme, vol. 6, núms. 3-4, 1973.

-: Convention Européenne des Droits de l'Homme et Pacte des Nations Unies relatif aux droits civils et politiques: décisions du Comité des Ministres du Conseil de l'Europe. Zeitschrift für ausländiches öffentiliches Recht much Völkerrecht, 1970.

ERmacora, F.: Menchenrectskinvention-Just publium europaem. Deutsches Verwaltmghblatt, 1969. 
EVRIGENIS, D.: L'interaction entre la dimensión internationale et la dimensión nationale de la Convention Européenne des Droits de l'Homme. Festschrift für Herman Mosler, Berlín, Heidelberg, New York, Springer, 1983.

Evrigenis, D.: Reflections on the national dimension of the European Convention on Human Rights. Proceding of the Colloquy about the ECHR Atenas, septiembre 1978, Conseil de l'Europe, septiembre 1979.

-: «Legal and constitutional implications of Greek accession to the European Communities, Common Market Law Review, vol. 17, 1980.

-: Le rôle de la Convention Européenne des Droits de l'Homme. New Perspectives for a Common Law of Europe, Ed. M. Cappeletti, 1979.

EzEIJIOFOR, G.: Protection of human rigths under law, London 1954.

FaIRÉn GuILlén, V.: «Algunos problemas procesales suscitados por el artículo 6 de la Convención Europea de los Derechos del Hombre", Revista de Instituciones Europeas, vol. 7, 1980.

FALK, R.: «Comparative Protection of Human Rights in Capitalist and Socialist Third World Countries", Universal Human Rights (New York), vol. 1, n. $^{\circ} 2,1979$.

Faure, A.: «La Convention Européenne des Droits de l'Homme», Schweizerisches Jahrbuch für Internationales Recht, 1966.

FAvoreu, L.: “Le Conseil constitutionnel et le Droit International», Annuaire Française de Droit International, vol. 23, 1977.

FAWCETT, J. E. S.: The European Convention on Humans Rights. Recent Trendes, Current Legal Problems, 1971, vol. 24. 
FAWCETT, J. E. S.: The Application of the European Convention on Human Rights. Clarendon Press, Oxford 1969.

Fernandez de la Vega Sanz, J.: Derechos Humanos y Consejo de Europa. Centro de Publicaciones de la Secretaría General Técnica del Ministerio de Justicia, Madrid 1985.

FeRnANDez SANChez, P. A.: Las obligaciones de los Estados en el marco del Convenio Europeo de Derechos Humanos, Ministerio de Justicia, Publicaciones, Madrid 1987.

FERnANDEZ TOMÁs, A. F.: «La adhesión de las Comunidades Europeas al Convenio Europeo para la protección de los Derechos Humanos (CEDH): un intento de solución al problema de la protección de los derechos fundamentales en el ámbito comunitario", Revista de Instituciones Europeas, vol. 12, n. ${ }^{\circ}$, septiembre-diciembre 1985.

Ferrari-Bravo, L.: «Problemi tenici dell'adesione delle Comunità Europee alla Convenzione Europee dei Diritti dell'Uomo", Rivista di Diritto Europeo, 1979, vol. 4.

FIX Zamudio, H.: Los Tribunales Constitucionales y los Derechos Humanos, Ed. Porrúa, México 1985.

-: «El Derecho de amparo en México y en España, su influencia recíproca», Revista de Estudios Políticos, n. ${ }^{\circ}$, Madrid 1979.

-: La protección jurídica y procesal de los derechos humanos ante las jurisdicciones nacionales, Universidad Autónoma de México, Ed. Civitas, México 1985.

Fonseca, G. DA, y VILLAPANDo, W.: Defensa de los derechos humanos, Ed. Tierra Nueva, SRL, 1976.

FORSYTHE, D.: «Political prisoners: the law and politics of protection», Vanderbilt Journal of Transnational Law (Nashville, Tenn.), vol. 9, Spring 1976.

Forsythe, D., y Wiseberg, L.: «Human Rights Protection: A Research Agenda", Universal Human Rights (New York), vol. 1, n. ${ }^{\circ} 4,1979$.

FrancK.: «Le Conseil Constitutionnel et les règles du Droit International», Revue Général de Droit International Public, n. ${ }^{\circ} 79,1975$.

FREUND, J.: La Convention Européenne des Droits de l'Homme et la politique. La protection international des droits de l'homme dans le cadre européen, Paris, Dalloz, 1961. 
Friginal Fernández-Villaverde, L.: La protección de los derechos fundamentales en el ordenamiento español, Ed. Motecorvo, Madrid 1981.

FROMONT, M.: «La protection juridictionnelle du particulier contre le pouvoir exécutif en France», Revista del Instituto de Derecho Comparado, Barcelona, enero-junio, 1955.

FROWEIN, J. A.: The guarantees afforded by the institutional machinery of the convention. Privacy and Human Rights, 3nd Int. Colloquy on the European Commission on Human Rights, Manchester, University Press, 1973.

-: "The European and the American Conventions on Human Rights. A comparison», en Human Rights Law Journal, vol. I, 1980.

-: European Convention on Human Rights. Encyclopedia of Public International Law, R. Bernhardt (ed. 1985).

GAJA, G.: «Le ius cogens de la Convention de Vienne», RCADI, vol. 172, 1981-III.

Galeottı, S., y Rossı, B.: «El Tribunal Constitucional en la nueva Constitución española", Revista de Estudios Políticos, n. ${ }^{\circ}$ 7, 1979.

GANJI, M.: International protection of human rights, Libraire E. Droz, Géneve 1962.

Ganshof Van Der Meersh, W. J.: Les Droits de l'Homme et la Constitution belge. Mélanges offerts à Polys Modinos, Ed. A. Pedone, Paris 1968.

-: «La référence au droit interne des Etats contratans dans la jurisprudence de la Cour Européenne des Droits de l'Homme", Revue Internationale de Droit Comparé, vol. 32, 1980.

-: "Le respect des droits fondamentaux de l'homme, condition exigée du droit des Etats européens", Revue de Droit International et de Droit Comparé, vol. 60, 1983.

-: European Court of Human Rights. Encyclopedia of Public International Law R. Bernhardt (ed.), 1982.

-: L'adhésion des Communautés Européennes à la Convention Européene des Droits de l'Homme, Brylant Editeur et Vander Editeur, Bruxelles 1981.

Garcia de EnterriA, E., et al.: Èl sistema europeo de protección de los derechos humanos, Civitas, Madrid 1976.

Garcia Gomez, M.: Derechos humanos y Constitución española, Alhambra, Madrid 1985. 
Garcla-Huidobra, J.: Defensa y rescate de los derechos humanos, Valparaíso 1987.

Garcia Morillo, J.: El amparo judicial de los derechos fundamentales, Ministerio de Justicia. Secretaría General Técnica, Madrid 1985.

Garcia Ruiz, J. L.: El recurso de amparo en el Derecho español. Prólogo de J. de Esteban y apéndice de P. Pérez Tremps, Ed. Nacional, Madrid 1980.

Garcia ToRres, J., y Jiménez Blanco, A.: Derechos fundamentales y relaciones entre particulares. La "Drittwirkung" en la jurisprudencia del Tribunal Constitucional», Cuadernos Civitas, Madrid 1986.

GellHORN, W.: Ombudsman and Others Citizen's Protectors in Nine countries. Cambridge, Mass., Harvard University Press, 1967.

GIL-Robles, A.: El defensor del pueblo, Civitas, Madrid 1979.

Goguel, F.: Vingt leçons sur la jurisprudence du Conseil Constitutionnel, Institut d'Études Politiques de Paris, Policop, 1982.

Golsong, H.: «Implementation of International Protection of Human Rights», RCADI, 1963-III.

-: Quelques réflexions à propos du pouvoir de la CEDH d'accorder une satisfaction équitable, René Cassin Amicorum Discipulorum Liber, I, Paris, 1969.

Gomez-Ferrer Morant, T.: La tutela judicial efectiva como derecho fundamental, en el libro de la Jurisprudencia del Tribunal Constitucional, Institución «Fernando el Católico», Zaragoza 1985.

Gomez Robledo, A.: «Le ius cogens international: sa genèse, sa nature, ses fonctions", RCADI, vol. 172, 1981-III.

Gómez SAnChez, Y.: Familia y matrimonio en la Constitución española de 1978, Congreso de los Diputados, Madrid 1990.

GonzAlez CAMPo, J.: «La protección de los derechos humanos en las Naciones Unidas", en ONU, año XX, Madrid, Ed. Tecnos, 1966.

Green, L. C.: The European Convention on Human Rights. World Affairs, 1951.

Greembarg, J., y Shalit, A.: «New horizons for Human Rights the European Convention, Court and Commission of Human Rights», Columbia Law Review, 1963.

GreensPan, M.: "The protection of human rights in time of warfare", Israel Yearbook on Human Rights (Tel Aviv), vol. 1, 1971. 
GrenentieRI, V.: «La Cour Européenne des Droits de l'Homme et le procés civil», Revue Trimestrelle de Droit Européenne, n. ${ }^{\circ}$ 3, 1969.

Grillo-Pasquarelli, E.: Commisśione Europea dei Diritti dell'Uomo. Condizioni di ricevibilita comuni ai ricorsi statali e individuali. Diss., Torino 1968/69.

Gros EsPIELL, H.: «Le système interaméricaine comme régime régional de protection internationale des droits de l'homme", Recueil des cours (Hague Academy of International Law), vol. II, 1976.

GUARNERI, G.: "The protection of Human Rights in the framework of the Council of Europe during 1969", Revue des Droits de l'Homme, vol. 3, n. ${ }^{\circ} 2,1970$.

GuggenHeIM, M. H.: "The implementation of human rights by the UN Commissioner on the status of women: a brief comment", Texas International Law Journal (Austin, Tex.), vol. 12, n. ${ }^{\circ}$ 2-3, 1977.

Guillermin, G.: La Cour Européenne des Droits de l'Homme, Paris 1978.

GUINAD, J.: "La règle de l'épuisement des voices de recours internes dans le cadre de systèmes internationaux de protection de l'homme", Revue belge de Droit International, 1968.

GUZmAn CaRRAsco, M. A.: No intervención y protección internacional de los derechos humanos. Quito (Ecuador), Editorial Universitaria, 1963.

HAKSAR, U.: Minority protection and international bill of human rights, Bombay, Allied Publishers, 1974.

IMBERT, P. H.: «Reservations and Human Rights Conventions", The Human Rights Review (London), vol. 6, n. ${ }^{\circ} 1,1981$.

INSTITUT D'Études EuRopéenNES dE L'UNIVERSITÉ LIBRE DE BRUXELLES: Les droits de I'homme en droit interne et en Droit International, Bruselas 1968.

JaCOBS, F. G.: The European Convention on Human Rights, Oxford, Clarendon Press, 1975.

-: "The Extension of the European Convention on Human Rights to Include Economic, Social and Cultural Rights», Human Rights Review (London), vol. 3, 1978.

JakoVLJEVIC, B.: New International Status of Civil Defence: As an Instrument for Strenghening the Protection of Human Rights. The H. Martinus Nijhoff, 1981.

JENKS, C. W.: Human rights and the international labour standards. New York, Praeger, 1960. 
JENKS, C. W.: «The international protection of freedom of association for trade union purposes", Recueil des cours (Hague Academy of International Law), vol. I, 1955.

-: The International protection of trade union freedom. London, Stevens, 1957.

-: La Organización Internacional del Trabajo y la protección de los derechos humanos de América, Buenos Aires, Universidad Nacional de Buenos Aires, 1962.

JOYCE, J. A.: World Labour Rights and their Protection, Croom Helm, London 1980.

Jurisprudencia del Tribunal Europeo de Derechos Humanos: «25 años de Jurisprudencia 1959-1983". Boletín de Jurisprudencia Constitucional, Madrid 1988.

KELLY, J. M.: «Protection of the Individual Against the Executive in the Republique of Ireland", en Gerichtsschutz gegen die Executive, Köln, Berlín, Bonn 1969.

KISS, A. Ch.: «La protection internationale du droit de l'enfant à l'éducation», Revue des droits de l'HommelHumann rights journal (Paris), vol. VI, n. ${ }^{\circ} 3-4,1973$.

-: Etudes fonctionelles des organes européens de protection internationales des Droits de l'Homme - la fonction de conciliation-. Colloque International sur la Convention Européenne des Droits de l'Homme, organisé par le Centre Universitaire des Hautes Études Européennes de Strasbourg et la Revue des Droits de I'Homme, vol. II-2, 1969.

-: La Convention Européenne des Droits de l'Homme et le système de garantie du Droit International Public. La protection internationale des droits de l'homme dans la cadre européenne, Paris-Dalloz, 1961.

Koopmans, T.: Constitutional protection of Equality, A. W. Sijthoff, Leyden 1975.

Kovar, R.: "L'autorité des arrêts et des résolutions des organes de protection". Revue des Droits de I'Homme, vol. VI-I, 1973.

KUNZ, J. F.: «Sanctions in International Law», 54, AJIL, 1960. 
KUTNER, L. (Ed.): The human right to individual freedom: a symposium on world habeas corpus. Coral Gables, Fla. University of Miami Press, 1970.

Kruger, J. C.: «The European Commission on Human Rights», Human Rights Law Journal, vol. I, 1980.

LADOR-LEDERER, J. J.: International group protection: aims and mets in human rights. Leyden, Sithoff 1968.

-: "The role of treaty law in the protection of human rights", Israel book on Human Rights (Tel Aviv), vol. 2, 1972.

LAESTADIUS, J.: Obligations of States under the European Convention on Human Rights (Mimeografía Consejo de Europa, 1984).

LALIVE, J. F.: Quelques réflexions sur la protection des droits de l'homme en dehors de l'Europe. Internationales Kollequim uber Mendhenrechte, Berlin 1968.

Lalive, J. F., y VASAK, K.: "Jurisprudence de la Commission de la Cour Européenne des Droits de l'Homme et du Comité des Ministres du Conseil de l'Europe», Journal de Droit International, 1964.

LANNUNG, H.: «Human Rights and the multiplicity of European systems for international protection», Human Rights Journal, vol. V, 1973.

LAUTERPACHT, H.: «The international protection of human rights", Recueil des cours, Academy of International Law, vol. 70, 1947.

-: An international bill of the rights of man, New York 1945.

—: International law and human rights, New York, Praeger, 1950.

LeBLANC, L. J.: The OAS and the Promotion and Protection of Human Rights. The Hague, Martinus Nithoff 1977.

LEE, L. K.: «European integration and the protection of human rights», The George Washington Law Review, vol. 31, 1962/63.

LEIFER, M.: Human Rights in the European Community. The development and operation of the European Convention for the protection of Human Rights. Australian Outlook, vol. 15, 1961. 
LeVIE, H. S.: Protection of War Victims: protocol 1 to the 1949 Conventions, 4 vols., Dobbs Ferry, N.Y., Oceana, 1979-1981.

LIEBSCHER, V.: «Austria and the European Convention for the Protection of Human Rights and Fundamental Freedoms", Journal of the International Commission of Jurisits, vol. IV, 1963.

Linde Paniagua, E.: Amparo ordinario, amparo constitucional y Convención Europea para la Protección de los Derechos Humanos y Libertades Fundamentales, dentro del colectivo: El Tribunal Constitucional, vol. II.

- El sistema europeo de protección de los Derechos Humanos. Estudio de la Convención y de la jurisprudencia del Tribunal Europeo de derechos humanos. Ed. Civitas, 1979.

Linde, E.; Ortega, L. I.; SÁnChez Morón, M.: El sistema europeo de protección de los derechos humanos. Ed. Civitas, S. A., 2. ${ }^{a}$ edición, Madrid 1983.

LIPPMAN, M.: «Human Rights Revised: The Protection of Human Rights under the International covenant on Civil and Political Rights", Netherlands International Law Review, vol. XXVI, n. ${ }^{\circ}$ 3, 1979.

LOAGIANI, J. F.: La commissione nella Convenzione Europea dei Diritti del/'Uomo. Milano, A. Giuffré, 1969.

LOPEZ GARRIDO, D.: Libertades económicas y derecho fundamental en el sistema comunitario europeo. Tecnos, S. A., Madrid 1986.

Louls, J. V.: «Droits de I'homme et élargisement des Communautés Européennes", Revue des Droits de l'Homme, vol. 5, n. ${ }^{\circ} 4,1973$.

LUARD, D. E. T. (Ed.): The international protection of human rights. New York, Praeger, 1967.

LUINI DEL RUSSo, A.: International protection of human rights. Washington, D. C., Lerner Law Books Co., 1971.

Luzzatto, R.: La Corte Europea dei Diritti dell'Uomo e la riparazione della violazioni della Convenzione. Studi in onore di Manlio Udina, Giuffré Ed., Milano 1975. 
MACBRIDE, S.: «The European Court of Human Rights», Journal of International law and Politics, n. ${ }^{\circ}$ 3, New York University, 1970.

MACNAIR, L.: The European Convention of 1950 for the protection of Human Rights and Fundamental Freedoms. The Expansion of International Law Jerusalem, Hebrew University, 1962.

MARIE, J. B.: Glossaire des droits de l'homme: termes fondamentaux dans les instruments universels et regionaux. Glossary of Human Rigths: Basic Terms in Universal and Regional Instruments. Paris, Éditions de la Maison des Sciences de l'Homme, 1981.

MoHoneY, P.: «Developments in the Procedure of the European Court of Human Rights: the Revised Rules of Court", Yearbook of European Law, vol. 3.

MANOS, J.: La clause de dérogation dans la Convention Européenne des Droits de l'Homme (article 15 de la Convention). Université de Genève, 1974.

MARIN LOPEZ, A.: «La garantía de los derecho humanos en el ámbito europeo", Revista de Instituciones Europeas, vol. 2. 1975.

-: Los derechos del hombre en el Consejo de Europa: el Cuarto y Quinto Protocolos al Convenio Europeo de 1950. Libro homenaje a D. Antonio de Luna, Instituto Francisco de Vitoria, CSIC, Madrid 1968.

-: «El problema de las relaciones entre el Derecho Interno y el Derecho Internacional en las Constituciones», REDI, vol. IV, 1952.

Martínez Rúlz, L. F.: «La fuerza obligatoria de los tratados internacionales y el orden jurídico interno", REDI, vol. XXII, n. ${ }^{\circ} 1,1969$.

MATSCHER, F.: La posizione processuale dell'individuo como riccorrente agli organi della Convenzione Europea dei Diritto dell'Uomo. Studi in onore Giuseppe Sperdutti, Dott, A. Giuffré, Ed. Milano 1984.

MCCARTHY, T. E.: "The international protection of human rights-ritual and reality", The International and Comparative Law Quarterly (London), vol. 25, april 1976.

McDougal, M.; Lasswell, J., y CHen, L.: «Human Rights and World Public Order: Human Rights in Comprehensive Context", Northwestern University Law Review, vol. 72, 1977. 
McDougal, M.; LASSWELL, J., y CHEN, L.: «The protection of aliens from discrimination and world public order: responsibility of states conjoined with human rights", American Journal of International Law (Washington, D. C.), vol. 10, july 1976.

MENDELsohn, M.: «The impact of European Community law on the implementation of the European Convention on Human Rights», Human Rights Files, n. ${ }^{\circ}$ 6, Directorate of Human Rights, 1984.

MENGozZI, P.: The control of the respect human rights within the European Convention in relation to the inter-American Implementation system. Proceeding of the Colloquy about the E.C.H.R., Atenas, september 1978, Conseil de l'Europe, september 1979.

MERlE, M.: «La Convention Européenne des Droits de l'Homme», Revue de Droit Public, 1951.

-: "La Convention Européenne des Droits de l'Homme et des libertés fondamentaux», Revue de Droit Public et de la Science Politique, 1951.

MERON, T.: «A Report on the N.Y.U. Conference on Teaching International Protection of Human Rights», New York University Journal of International Law and Politics, vol. 13, 1981.

MERTENS, P.: Le droit de recours effectif devant les instances nationales en cas de violation d'un Droit de l'Homme (dissertation), Institut d'Etudes Européennes, Université Libre de Bruxelles, 1973.

-: Origines et fondements d'un droit de recours interne en cas de violation d'une norme de Droit International. Les recours des individus devant les instances nationales en cas de violation du droit européen. Colloque organisé les 24 et 25 avril 1975, Bruxelles, Lancier, 1978.

—: «Les droits de quel homme?», Synthèses (Paris-Bruxelles), n. ${ }^{\circ}$ 273-274, march-april 1969.

-: L'imprescriptibilité des crimes de guerre et contre l'humanité. Bruxelles, Éditions de l'Université de Bruxelles, 1974 (Études de Droit International et de Droit Pénal Comparé, n. ${ }^{\circ} 6$ ).

MEYER, J.: The international control machinery. Proceeding of the Colloquy about the E.C.H.R., Atenas, september 1978. Conseil de l'Europe, september 1979. 
MiAJA DE LA MUelA, A.: «El agotamiento de los recursos internos como supuesto de las reclamaciones internacionales", Anuario Uruguayo de Derecho Internacional, tomo II, 1963, Montevideo 1964.

MiChALSKA, A.: «Uniwersalizm i regionalizm w miedzynarodeowej ochronie praw ezlowieka (Universalism and regionalism in the international protection of human rights)", Ruch Prawniczy Ekonomiczny $i$ Sociologiczny (Poznan, Poland), vol. 36, n. ${ }^{\circ} 2,1974$.

MiehleR, H., y Petzold, H.: European Convention on Human Rights. Texts and Documents. Carl Heymanns Verlag K.G., Köln, Berlín, Bonn, München 1984.

Miele, M.: L'article 50 della Convenzione Europea sui Diritti dell'Uomo e le sue prime applicazione giurisprudenziali. Studi in onore di Maulio Unina, Ed. Milano, 1975.

MIKAELSEN, L.: European protection of Human Rights. The practique and procedure of the European Commission of Human Rights on the admissibility cations from individuals and states. Alphen aam dem Rijn, 1980.

-: European Protection of Human Rights: The Practice and Procedure of the European Commission on Human Rights on the Admissibility of Applications from Individuals and States. The Hague, Martinus Nijhoff, 1980.

MIYAZAKI, S.: «Strasbourg Organisation and International protection of Rights in Europe", Meiji Law Review, vol. 35, 1961/62.

Modinos, P.: «La Convention Européenne des Droits de l'Homme», Revue de Droit International Public, 1956.

-: «La Convention Européenne des Droits de l'Homme: ses origines, ses objectifs, ses réalisations», Annuaire Européen, 1953.

Monconduit, F.: «Commission Européenne des Droits de l'Homme. Bilan de Jurisprudence», janvier 1969, mai 1973, en: Anuales de Droit, n. ${ }^{\circ}$ 1-2, 1985. 
MonCONDUIT, F.: «Étude fonctionelle des organes européennes de protection nationales des Droits de l'Homme, la fonction d'enquête et d'instruction. Court International sur la Convention Européenne des Droits de l'Homme, par le Centre Universitaire des Hautes Études Européennes de Strasbourg", en Revue des Droits de l'Homme, 1969.

MONTIEL y DUARTE, I.: Estudio sobre las garantías individuales, México 1973 (2. ${ }^{a}$ ed., facsímil), Porrúa, Buenos Aires-México 1972.

MOREILlon, J.: Le Comité international de la Croix-Rouge et la protection des détenus politiques. Lausanne, Institut Henry-Dunant, Éditions, l'Age d'homme, 1973.

Morenilla Rodriguez, J. M.: El Convenio Europeo de Derechos Humanos. Ámbito, órganos y procedimientos. Centro de Publicaciones de la Secretaría General Técnica del Ministerio de Justicia, 1985.

-: “La protección internacional de los derechos humanos", Boletín de Información del Ministerio de Justicia, 15 de febrero 1984, n. ${ }^{\circ} 1.338$.

MORRISSON, C.: "Margin of appreciation in European human rights law?", Revue des Droits de l'Homme, vol. 6, 2, 1973.

-: «Restrictive interpretation of sovereignty treaties: the practice of the European Human Rights Convention system», The international and Comparative Law Quarterly, vol. 19, n. ${ }^{\circ} 3,1970$.

-: The developing European Law of Human Rights, European Aspects, serie E, 7, Leyden, A. W. Sijthoff, 1967.

-: The European Human Rights Convention systems as a Function of Enterprise. Universal Rights, vol. I, 1979.

Moskowitz, M.: International Concern with Human Rights, Leiden 1974.

MosLer, H.: «L'aplication du Droit International Public par les tribunaux nationaux», RCADI, vol. I, 1957.

-: La procédure de la Cour Internationale de Justice et de la Cour Européenne des Droits de l'Homme. René Lassier Amicorum Discipulorum, vol. I, 1969.

Moureaux, S.: «La Convention Européenne des Droits de l'Homme et la réalité de son application quotidienne», Synthèses, número especial, 1969. 
Muller-RAPPARD, E.: «Le droit d'action en vertu des dispositions de la Convention Européenne des Droits de l'Homme», Revue Belge de Droit International, 1968.

-: "The European Commission and Court of Human Rights", Bulletin of the World Federation of United Nations Associations, 1968.

NARTOWSKI, A. S.: «The UNESCO system of protection of the right to education", Polish Yearbook of International Law (Wroclaw), vol. 6, 1974.

NAskov-PerRakis, A.: La satisfaction équitable accordée par la Cour Européenne des Droits de l'Homme. Komotini, Ed. A. Sakkonlas, 1980.

NEDJATI, Z. M.: Human Rights and fundamental freedoms. Nicosia 1972.

-: «Human Rights under the European Convention», Europeans Studies in Law, vol. 8, 1978, Amsterdam, North-Holland Publishing Company, 1978.

NDIAYE, B.: «De l'individu et de sa collaboration avec les organismes internationaux de protection des droits de l'homme", 1974 Annales Africaines (Dakar), 1975.

NeWman, F.: The Convention and World wide Human Rights, some inconoclastic inquiries, Bruxelles Colloquy, 1983.

NiEKERK, B. VAN: «Human Rights in Europe: some aspect of the practical application of the European Convention on Human Rights", SouthAfrican Law Journal, 1973.

NorgaARD, C. A.: European Commission of Human Rights. Encyclopedia of Public International Law, P. Bernhardt (ed.), 1985.

NoRRIs, R.: «Bringing Individual Petitions Before the Inter-American Commission", Santa Clara Law Review, vol. 20, 1980.

O'BOYLE, M.: «Practice and procedure under the European Convention on Human Rights", Santa Clara Law Review, vol. 20, 1980.

-: Strasbourg. A system of supervision for the protection of Human Rights in Europe. Understanding human rights: published by Irish Institute of Ecumenic, chapter 10, Alan Faleoner, 1980.

O'CONNOR, T.: «lllegitimacy and the European Convention Human Rights", Irish Law Times and Solicitors Journal, 15 july-2 september 1978.

O'DonNelL, T. A.: «The Margin of appreciation Doctrine, Stand in the Jurisprudence of the European Court of Human Rights», Human Rights Quarterly, vol. 4, 1982. 
Ollero TAssara, A.: Derechos humanos y metodologia jurídica, CEC, Madrid 1989.

OPSAHL, T.: «The Protection of Human Rights in the Council of Europe and in the United Nations", European Yearbook (The Hague), vol. 26, 1980.

-: Réglement amiable des litiges dans le respect des droits définis dans la Convention Européenne des Droits de l'Homme. Comunicación presentada en el VI Coloquio Internacional sobre el Convenio Europeo de Derechos Humanos, Sevilla, 13-16 noviembre de 1985.

-: «The protection of civil and political rights in Norway», Revue des Droits de l'Homme, vol. VIII, 1975.

PAHR, W. P.: «La dinamique de la Convention Européenne des Droits de l'Homme», Revue des Droits de l'Homme, vol. II, n. ${ }^{\circ}$ 2, 1969.

--: «Étude fonctionelle des organes européens de protection internationaux des Droits de l'Homme -la fonction d'information-». Colloque International sur la Convention Européenne des Droits de l'Homme, organisé par le Centre Universitaire des Hautes Études Européennes de Strasbourg, en la Revue des Droits de I'Homme, vol. II, 1969.

Palaskas, M.: La Convention Européenne des Droits de l'Homme et le Droit International. Mémoire présenté au Centre des Hautes Études Européens de Strasbourg, 1960.

Panzera, A. F.: «ll potere della Corte Europea dei Diritti dell'Uomo di accord un'equa riparazione alla parte lesa», Rivista di Diritto Europeq, 1974.

-: "La Constituzione Spagnola del 1978 e il Diritto Internationale», Rivista di Diritto Internazionale, vol. 62, 1979.

-: Le pouvoir de la Cour Européenne des Droits de l'Homme d'accord une satisfaction équitable à la partie léssé. Les clauses facultatives de la Convention Européenne des Droits de l'Homme. Table ronde, Bari, Levante, 1982.

Pardos Pérez, J. L.: Protección internacional del individuo. l: Convención Europea de Derechos del Hombre y Libertades Fundamentales, Madrid 1963.

Pastor Ridruejo, J. A.: La Convención Europea de Derechos del Hombre. Jus cogens international. Estudios de Derecho Internacional. Homenaje al profesor Miaja de la Muela, Ed. Tecnos, Madrid 1979.

Peces-Barba, G., y otros: Derecho Positivo de los Derechos Humanos, Editorial Debate, Colección Universitaria, Madrid 1987. 
Pelloux, R.: Les arrêts de la Cour Européenne des Droits de l'Homme dans les affaires Stögmullers et Matznetter. A.F.D.I., 1970, pp. 343 y ss.

-: Précédents et caractères généraux de la Convention Européenne. La protection international des Droits de l'Homme dans le cadre européenne. Paris, Dalloz, 1961.

-: «La Cour Européenne des Droits de l'Homme», Revue des Droits de l'Homme, vol. I, n. ${ }^{\circ}$ 1, 1968.

-: La protection internationale des Droits de l'Homme dans le cadre européenne. Cours donné à l'Institut des Hautes Études Internationales de l'Université de Paris, 1960-61 (mimeografía).

Pérez LuÑo, A. E.: «Estado de Derecho y derechos fundamentales», en Los derechos humanos. Significación, estatuto jurídico y sistema, Universidad de Sevilla, 1979.

Perring, G.: «La Commission Européenne des Droits de l'Homme», Zeitschrift für Scheweizerisches Recht, vol. 94, n. ${ }^{\circ} 4,1975$.

PescatoRE, P.: «Les droits de l'homme et l'intégration européenne», Cahiers de Droit Européenne, n. ${ }^{\circ}, 1968$.

-: «The protection of human rights in the European Communities presented to the Parlamentary conference on Human Rights in Viena, 18-20 october», Common Market Law Review, vol. 9, n. ${ }^{\circ}$ 1, 1972.

Petersmann, H. G.: «The protection of fundamental rights in the European Comunities», European Yearbook, vol. XXXII, 1975.

Petren, S.: La saisine de la Cour Européenne para la Commission Européenne des Droits de l'Homme. Mélanges offerts à Polys Modinos, Ed. A. Pedone, Paris 1968.

Petzold, H.: «The European Convention on Human Rights in the Austrian Constitutional Court», The British Yearbook, 1972-73.

-: La Convention Européenne des Droits de l'Homme. Jurisprudence et documents. Recueil pour les étudiants en Droit International des Droits de l'Homme. Institut International des Droits de l'Homme, Strasbourg, $4^{\text {ème }}$, Köln, Carl Havmanns Verlag, 1981.

Pinheiro Farinha, J. D.: Convençao Europeia deos Direitos do Homen. Sociedade Tipografica, Lisboa 1980. 
PINTO, R.: Conséquences de l'application de la Convention à la fois sur le droit interne, et sur le plan international. Les Droits de l'Homme en Droit International, Actes du II Colloque International sur la Convention Européenne des Droits de l'Homme, Vienne, 18-20 oct. 1965, Bruxelles, Press Universitaires, 1968.

-: Consequences of the application of the Convention in municipal and international law. Proceedings of the 2nd International Conference on the European Convention on Human Rights, held in Vienna, 18-20 oct. 1965. Manchester Unive. Press; Dobbs Ferry, N.Y., Oceana Publ. 1968.

-: Les Organisations européennes. Chapitre II. Le Conseil de l'Europe et la sauvegarde des Droits de l'Homme et des Libertés Fondamentaux. Payot, Paris 1965.

Premont, D.: «United Nations Procedures for the Protection of All Persons Subjected to Any Form of Detention or Imprisonment", Santa Clara Law Review (Santa Clara), vol. 20, 1980.

Presidenza del Consiglio deI Ministro: «La Protezione Internazionale dei diritto dell' uomo", Suplemento alla Rivista Vita Italian-Documenti e Informazioni, n. ${ }^{\circ} 2,1979$, Quaderno n. ${ }^{\circ} 30$.

РотовsкY, G. Von: «Protection of trade union rights: Twenty years work by the Committee on Freedom of Association», International Labour Review, january 1972.

POULANTZAS, N. M.: «International protection of human rights: implementation procedures within the framework of the ILO", Revue Hellénique de Droit International (Athens), vol. 25, 1972.

PrZetAcZ̈NIK, F.: «L'attitude des Etats socialistes à l'égard de la protection internationale des droits de l'homme», Revue des Droits de l'Homme/ Human rights journal (Paris), vol. VIII, n. ${ }^{\circ}$ 1, 1974.

RABOSSI, E.: «La teoria de los derechos humanos naturalizada", en Revista del Centro de Estudios Constitucionales, n. ${ }^{\circ}$ 5, 1990.

RAMACHANDARAN: Fundamental rights and constitutional remedies, 2nd edition, Lucknow, Delhi, Eastern Book Company, 1970, 2 vols.

RAYMOND, J.: «Les droits garantis par la Convention de sauvegarde des Droits de l'Homme et des Libertés Fondamentaux", Revue des Droits de l'Homme, n. ${ }^{\circ}$ 2, 1970.

Recuell des Travaux Preparatolres: De la Convention Européenne des Droits de l'Homme. Council of Europe. Collected édition of the travaux préparatoires of the European Convention au Human Rights, vols. 1, 2, 3, 4, 5. Nijhoff, 1976. 
Resich, Z.: «La Commission des Droits de l'Homme des Nations Unies», Revue de Droit Contemporain (Bruxelles), n. ${ }^{\circ} 1,1968$.

-: Effectiveness of human rights defense in the UN Organization (In Polish), Nowe Prawo (Warsaw), vol. 30, march 1974.

Retton, P. D.: «The Suspension of Guarantees: A Comparative Analysis of the American Convention of Human Rights and the Constitutions of the States Parties", The American University Law Review, vol. 30, 1980.

REYNOLDS, P. D.: «On the protection of human subjetcs and social sciences», International Social Science Journal (Paris, UNESCO), vol. XXIV, n. 4, 1972.

Robertson, A. H.: Legal problems of European integration. Recueil des Cours de l'Académie de Droit International de La Haye, vol. 91, 1958.

-: "Le Conseil de I'Europe et les Droits», Rivista di Diritto Europeo, n. ${ }^{\circ} 4$, 1973.

-: "Le rôle du Comité de Ministres du Conseil de l'Europe. Colloque de Grenoble», 25-26 janvier 1973, Revue des Droits de l'Homme, vol. 6, n. ${ }^{\circ} 3,1973$.

-: The Commission and the Court of Human Rights. The law of International Institutions in Europe, Manchester, University Press, 1961.

-: "The European Convention for the protection of Human Rights", British Yearbook of International Law, 1950, pp. 145-163, 1951.

-: «The European Convention on Human Rights; educational aspects", The American Journal of Comparative Law, $\mathrm{n} .^{\circ} 2,1970$.

RoLIN, H.: «Has the European Court of Human Rights a future?», Harvard Law Journal, 1965.

-: "L'autorité des arrêts et des décisions des organes de la Convention Européenne des Droits de l'Homme", Revue des Droits de l'Homme, vol. VII.

-: «Les principes de Droit International Public», RCADI, 1950.

-: Vers un ordre public réellement international. Hommage d'une gestion de juristes au Président Basdevant, Ed. A. Pedone, Paris 1952.

RonzITTI, N.: «L'accettazione della Convenzione Europea dei Diritti dell'Uomo e delle sue clausole facoltative da parte degli stati membri del Consiglio", Rivista di Diritto Internazionale, vol. 50, 1957.

RosenNe, S.: «L'exécution et la mise en viguer des décisions de la Cour Internationale de Justice», 57, RGKIP, 1953. 
RotTola, A.: «ll problema della tutela dei diritti fondamentali nell'ambito ordinamento comunitario», Rivista di Diritto Europeo, 1978.

Roujou de BoubeE, G.: «La protection des Droits de l'Homme en Droit pénal française", Revue International de Droit Pénal, vol. 47, 1976.

Rovira Viñas, A.: El abuso de los derechos fundamentales, presentación de E. Tierno Galván, prólogo de J. Morodo, Ed. Península, Barcelona 1983.

Rowat, D. C. (ed.): The Ombudsman: Citizen's Defender. London, Allen and Unwin, 1965.

RuILoba Santana, E.: La regla del agotamiento de los recursos internos a través de las decisiones de la Comisión Europea de los Derechos del Hombre. Estudios de Derecho Internacional Público y Privado. Homenaje al Prof. Lui Sampil, tomo 1, Secretariado de Publicaciones, Universidad de Oviedo, 1981.

RuZIE, D.: «La Constitution française et le Droit International, à propos de la décision du Conseil Constitutionnel du 15 janvier 1975", Journal du Droit International, vol. 102, 1975.

SANCHEZ de LA TORRE: Teoria jurídica de los Derechos Humanos, IEP., 1972.

SÁNCHEZ MORÓN, M.: El recurso de amparo constitucional, CEC, Madrid 1988.

Sainz de Varanda, R.: Convención Europea de los Derechos del Hombre. Academia Aragonesa de Ciencias Sociales e Instituto de Estudios Europeos. Facultad de Derecho de la Universidad de Zaragoza, 1959.

SALVIOLI, G.: «La responsabilité des États et la fixation des dommages intérêts par les tribunaux», RCADI, III, 1929.

SANDEFER, D. V.: "Human Rights in the inter-American system», ard Law Journal (Washington, D.C.), vol. 11, n. ${ }^{\circ} 2,1965$.

SCHLEIFER, N.: «Territorial Asylum in the Americas: Practical Constitutions for Relocation", Lawyer of the Americas, vol. 12, 1980.

SCOBLE, H., y WISEBERG: «Human Rights NGOS: notes towards comparative analysis", Revue des Droits de l'Homme/Human Rights Journal (Paris), vol. IX, n. ${ }^{\circ} 4,1976$.

SCHACHOR-LANDAU, C.: “Protection of fundamental rights and sources of law in European community jurisprudence», Journal of World Trade Law (Twickenham, Middlesex, U.K.), vol. 10, may/june 1976. 
SHAEFFER, E.: «La mise en oeuvre de la protection des droits de l'homme dans le cadre de la Convention Européenne et du Droit Communautaire Européen", Revue Juridique et Politique. Indépendance et Coopération, t. 36, n. ${ }^{\circ} 1,1982$.

SCHEMAN, L. R.: "The Inter-american Commission on Human Rights», American Journal of International Law (Washington, D.C.), vol. 2.

SCHEIBER, A. P.: The Inter-american Commission on Human Rights. Leyden, Sijthoff, 1970.

SCHEIBER, M.: "La practique récente des Nations Unies dans le domaine de la protection des droits de l'homme", Recueil des Cours (Hague Academy of International Law), vol. II, 1976.

-: "Les Nations Unies et les droits de I'homme", Revue des Droits de l'Homme/Human rights journal (Paris), vol. II, n.. 1, 1969.

-: "Les organisations non-gouvernementales et l'oeuvre des Nations Unies dans le domaine de la protection des droits de l'homme", Synthèses (Dordrecht, Netherlands), 25 june 1970.

SCHeRmers, H. G.: "Judicial Protection of International Rights", German Yearbook of International Law, vol. 23, 1980.

SCHWELB, E.: «International Convention on Human Rights", The international and Comparative Law Quarterly, 1960.

-: On the Operation of the European Convention on Human Rights. International Organization (1964).

-: "The International Court of Justice and the human rights clauses of the Charter", American Journal of International Law (Washington, D. C.), vol. 66, 1972.

-: "The international measures of implementation of the International Covenant on Civil and Political Rights and of the Optional Protocol", Texas International Law Journal (Austin, Tex.), vol. 12, n. ${ }^{\circ} 2-3,1977$.

-: "The nature of the obligations of the States parties to the International Covenant on Civil and Political Rights", in René Cassin Amicorum Discipulorumque liber I, Paris 1969.

Sidjanski, A., y Castaños, S.: "La Convention Européenne des Droits de l'Homme», Journal de Droit International, Paris 1955.

SIDJANASKI, D.: "La protection internationale et européenne des droits de I'homme foundement et consequences", Revue Egyptienne de Droit International, vol. XII, 1956. 
SiEghART, P.: The International Law of Human Rights. Clarendon Press, Oxford 1983.

SIEGLERSCHMIDT, H.: Le lien entre la protection des droits fondamentaux dans la Communauté Européenne et le système de la Convention Européenne des Droits de l'Homme. Conseil de l'Europe. Actes du quatrième colloque, Rome, nov. 75 .

SNYTH, J. F.: The European Commission of Human Rights. The Ombudsman. Citizen's Defender, London 1965.

Sohn, L. B., y Buergenthal, T.: International Protection of Human Rights, Indianápolis, Bobbs-Merrill, 1973.

SORENSEN, M.: «Punti di contatto tra la Convenzione Europea dei Diritto dell'Uomo ed il Diritto delle Comunità Europee». Rivista di Diritto Europeo, 1978.

--: The enlargement of the Communities and the protection of Human Rights. Actes de la Conférence Parlamentaire sur les Droits de l'Homme, 18-20 octobre 1971.

SPICER, G. W.: The Supreme Court and Fundamental Freedoms. New York, Appleton-Century-Crofts, 1959.

SperdutI, G.: “Caratteri del sistema europeo di protezione dei Diritti dell'Uomo», Rivista di Diritto Internationale, vol. LVII, 1974.

-: Comment concevoir, dans sa spécificité, l'adhésion des Comités Européennes à la Convention de Rome sur la sauvegarde des droits de l'Homme et des Libertés Fondamentaux. Völkerrecht als Rechstsordning. International richtsbsarkeit. Menscheurechte. Festchrift für Hermann Mosler, Beriin, Heidelberg, New York, Springer, 1983.

-: "La Convenzione Europea dei Diritto dell'Uomo e il suo sistema di garanzie», Rivista di Diritto Internazionale, vol. 46, 1963.

-: «Le rattachement des Communautés Européenes à la Convention de Rome sur la sauvegarde des Droits de l'Homme et des Libertés Fondamentaux», Revue du Marché Commun, 1980.

--: Sur la garantie pour les ordres juridiques internes des droits mantenues dans la Convention Européenne des Droits de l'Homme. Mélanges Dehousse, Editions Labor, Bruselas 1979.

Steingerger, H.: La référence à la jurisprudence des organes de la Communauté Européenne des Droits de l'Homme devant les Tribunaux Nationaux. Comunicación presentada en el VI Coloquio Internacional sobre el Convenio Europeo de Derechos Humanos, Sevilla, 13-16 noviembre de 1985. 
Stock-Taking on The European Convention on Human Rigths: $A$ periodic note on the concret results achieved under the Convention the first thirty years, 1954 until 1984, Strasbourg, Council of Europe, 1984.

Susterhenn, A.: L'application de la Convention sur le plan du Droit interne de Protection Internationale des Droits de l'Homme dans le cadre européen, Dalloz, 1961.

TALIADOUROS, S.: "The system for the protection of human rights in the states of the E.E.C.», Revue Hellénique de Droit International, 1982-83.

TEITGEN, P. H.: «The temporal effect of the Indgments of the European Court of Justice of the European Communities", H.R.L.Y., vol. I, n. ${ }^{\circ} 1-4,1980$.

-: Bilan politique de la garantie européenne des Droits de l'Homme, Conseil de l'Europe, Actes du quatrième colloque, Rome, nov. 75.

Thomas, A. V. W., y THomas, A. J.: «Human Rights and the Organization of American States", Santa Clara Law Review (Santa Clara, Calif.), vol. 12, 1972.

TIWARI, S. C.: "The European Convention for the protection of Human Rights", The Indian Journal of International Law, 1964.

Torres del Moral, A.: Principios de Derecho Constitucional español, Ediciones Átomo, Madrid 1985.

ToRnARitis, Q. C., y Criton, G.: La Convention Européenne des Droits de l'Homme dans l'ordre juridique de la République de Chypre. Conseil de l'Europe. Actes du quatrième colloque, Rome, nov. 1975.

Touffalr, A.: "Orden Público en la Comunidad Europea», Revista de la Comisión Internacional de Juristas, n. ${ }^{\circ} 17$, dic. 1976.

TReChSeL, S.: Quelques réflexions sur l'importance du droit de recours individual. Les clauses facultatives de la Convention Européenne des Droits de l'Homme, Edizioni Levante, Bari 1974.

-: Vers la fusión des organes de contrôle: a la recherche d'une sortie de l'impasse, $2^{\text {ème }}$ Séminaire de Droit International et de Droit Européen, Neuchâtel, mars 1986.

Trueba Urbina, A., y Trueba Barrero, J.: Nueva legislación de amparo. Doctrina, textos y jurisprudencia, Ed. Porrúa, México 1978.

Truyol y SerRA, A.: Los derechos humanos. Declaraciones y convenios internacionales, Ed. Tecnos, Madrid 1982. 
URIBE VARGAS, D.: Los derechos humanos y el sistema interamericano, Ediciones Cultura Hispánica, Madrid 1972.

ValLe, Ch.: «Une application de l'article 50 de la Convention Européenne des Droits de l'Homme", Revue Générale de Droit international Public, 1972.

VALTICOS, N.: «Les normes de l'Organisation Internationale du Travail en matière de protection des droits de l'homme», Revue des Droits de I'HommelHuman rights journal (Paris), vol. IV, n. ${ }^{\circ} 4,1971$.

-: "Les méthodes de la protection internationale de la liberté syndicale", en Rec. des Cours, ya citado, 144, 1975-I.

VAN DIJK, P., y VAN Hoof, F.: The European Convention in theory and practice. Kluwer Deventer, 1984.

Vangeengergue, F.: La Convention Européenne des Droits de l'Homme. La Protection Internationale des Droits del l'Homme. Presses Universitaires de Lyon, 1981.

VAN PANHUYs, J. H. F.: “The Netherlands Constitution and International Law», American Journal of International Law, vol. 47, 1953.

-: «The Netherlands Constitution and International Law - a decade of experience-», American Journal of International Law, vol. 58, 1953.

Varela Feijoo, J.: La protección de los derechos humanos, Ed. Hispano europea, Barcelona 1972.

-: La protección de los derechos humanos, Jurisprudencia de la Comisión y Tribunal Europeo de Derechos del Hombre. Barcelona, Europa Ed., 1972.

VASAK, K.: «L'organisation politique et administrative internationale (Conseil d'Europe, Convention Européenne des Droits de l'Homme, garantis para la Convention)», Journal de Droit International, $\mathbf{n}^{\circ}{ }^{2}$, fasc. 155 f., 1972.

- Regional institutions for the promotion and protection of Human Rights - The Council of Europe- . The international dimensions of Human Rights, páginas 457-542. Westport, Connecticut, Greenwood Press, Paris, UNESCO, 1982.

-: La Commission Interaméricaine des Droits de l'Homme, Libraire Générale de Droit et de Jurisprudence, Paris 1968.

-: "La protección internationales des droits de l'homme sur le Continent americain", Österreichische Zeitschrift für öffentliches Recht (Vienna), vol. XVII, 1967. 
VASAK, K.: Institutions régionales de promotion et de protection des droits de l'homme. Les dimensions internationales dans les droits de l'homme, Paris, CO, 1978.

-: L'application des droits de l'homme et des libertés fondamentaux les jurisdictions nationales. Article 13 de la Convention Européenne des Droits de l'Homme. Rapport de Karel Vasak. Semaine de Brugges, 1965, Droit Comunautaire et Droit National. Brugges, De Tempel, 1965.

VEGLERIS, P.: Études fonctionelles des organes européens de protection internationales des droits de l'homme -la fonction de décision et de sanction-. International sur la Convention Européenne des Droits de I'Homme par le Centre Universitaire des Hautes Études Européennes des Strasbourg, Revues des Droits de l'Homme, 1969.

-: Modes de redressement des violations de la Convention Europée des Droits de l'Homme. Mélanges effects à Polys Modinos, Ed. A. Paris, 1968.

VERDOODT, A.: La protection des droit de l'homme dans les États plurilingues. Brussels, Editions Labor, Paris, Fernand Nathan, 1973.

Verdross, A.: States of the European Convention in the hierarchy of the rules of law. Human Rights in National and International Law, Ed. A. H. Robertson, 1968.

VIEIRA DE ANDRADE, J. C.: Derechos y garantías fundamentailes, n..$^{\circ}$ 60-61, 1989.

-: Vie privée et droits de l'homme. Actes du Troisième Colloque International sur la Convention Européenne des Droits de l'Homme (Bruxelles, 30 septembre-3 octobre 1970), Bruxelles 1973.

VILLANI, U.: L'obligo degli stati non ostacolare l'esecizio effectivo del diritto di ricorso individuale. Les clauses facultatives de la Convention Européenne des Droits de l'homme, Table ronde, Bari, Edizioni Levante, Bari 1974.

VILLEGER, M. E.: The new Court and its domestic and international context. Second Seminar on International Law and European Law, Neuchâtel, March, 1986. 
VILHJALMSSON, T.: "The protection of Human Rights in Ireland", Revue des Droits de l'Homme, vol. VIII, 1975.

Vis, W.: La réparation des violations de la Convention Européenne des Droits de l'Homme (note sur l'article 50 de la Convention) dans la protection internationale des droits de l'homme dans le cadre européen. Travaux du Colloque organisé par la Faculté de Droit et de Sciences Politiques et Economiques de Strasbourg, du 14 au 14 novembre, 1961. Ed. Dalloz, Paris.

VITTA, E.: «Analogie e influenze di Diritto Pubblico interno della Convenzione Europea per la salvaguardia dei Diritti dell'Uomo delle Libertà Fundamentale", en Rivista Trimestrale di Diritto Pubblico, n. ${ }^{\circ} 4,1958$.

WALDOCK, H.: «Human Rights in contemporary international law and the significance of the European Convention", en The International and Comparative Quarterly, Suppl. Inter. Law Series, n. ${ }^{\circ}$ 5, 1965.

-: «The efectiveness of the system set up by the European Convention on Human Rights", en Human Rights Law Journal, vol. 1, n. ${ }^{\circ}$ 1-4.

--: "The European Convention for the Protection of Human Rights and Fundamental Freedoms", en British Yearbook of International Law, 1958.

-: "The European Convention of Human Rights and Fundamental Freedoms", en British Yearbook of International Law, 1959.

-: The evolution of Human Rights concepts and application of the European Convention on Human Rights, en Mélanges offerts a Paul Reuter, Ed. Pedone, Paris 1981.

WALTER, H.: Die Europäische Menschenrechtsordnung, Colonia, Berlín 1970.

WEIL, G. L.: The European Convention on Human Rights. Background, developments and prospects, A. W. Sijhoff, Leyden 1963.

-: The evolution of the European Convention on Human Rights, en J. I. L. 1963.

WEIS, P.: "The denunciation of human rights treaties", en Revue des Droits de l'Homme, vol. 1, 1975.

Wiebringhaus, H.: «Extension de la Convention Européenne des Droits de l'Homme», en Rivista di Diritto Europeo, n. ${ }^{\circ} 2,1961$. 
Wiebringhaus, H.: Jurisprudence et procédure du Comité de Ministres du Conseil de l'Europe en vertu du premier paragraphe de l'article 32 de la Convention Européenne des Droits de l'Homme, en Mélanges offerts à Polys Modinos, ed. Pedone, Paris 1968.

-: La Convention Européenne des Droits de l'Homme et la Charte Sociale Européenne", en Revue des Droits de l'Homme, n. ${ }^{\circ} 2-3,19$.

-: Le droit européen des libertés fondamentaux et l'Année International des Droits de l'Homme», en Rivista di Diritto Europeo, 1968.

WILLIAMS, A.: "The European Convention on Human rights: a new use?", en Texas International Law Journal, vol. 12, 1977.

WIRSING, R. (Ed.): Protection of Ethnic Minorities. New York, Pergamon, 1981.

Wiseberg, L., y Scoble, H.: «Recent Trends in the Expanding Universe of Nongovernmental Organizations Dedicated to the Protection of $\mathrm{Hu}-$ man Rights", Denver Journal of International Law and Policy, vol. 8, special issue, 1979.

WOLF, F.: «Aspects judiciaires de la protection internationale des droits de I'homme par l'OIT", Revue des Droits de l'Homme/Human rights journal (Paris), vol. IV, n. ${ }^{\circ} 4,1971$.

Zavala, S.: La defensa de los derechos del hombre en América Latina (siglos XVI-XVIII), UNAM, México 1982.

ZULEEG, M.: «Fundamental rights and the law of the European Communities», en Common Market Law Review, vol. 8, n. ${ }^{\circ} 4,1971$.

Zumaquero, J. M.: «La Constitución española de 1978 y el Convenio Europeo de Derechos Humanos», en Revista de Fundamentación de las Instituciones Juridicas y de Derechos Humanos, vol. 8, 1981.

II. EFICACIA DE LOS DERECHOS HUMANOS A NIVEL INDIVIDUAL $Y$ FRENTE A TERCEROS

BALLARÍn IRIBARREN, J.: «Derechos fundamentales y relaciones entre particulares en la jurisprudencia del Tribunal Constitucional», Revista Es- 
pañola de Derecho Constitucional, año $8, n^{\circ} 24$, septiembre-diciembre, 1988.

BUERGENTHAL, T.: «Domestic status of the European Convention on Human Rights: a second look", Journal of the International Commission of Jurists (Genève), vol. 7, Summer 1966.

-: «Effect of the European Convention on Human Rights on the internal law of Member States", The International and Comparative Law Quarterly (London), supp. publ. n. ${ }^{\circ} 11,1965$.

Calongeropoulos-Stratis, S.: «L'efficacité des mécanismes juridictionnels de protection des personnes privés dans le cadre européen", Revue des Droits de l'Homme, 1973, en III Colloque de Grenoble, 25 et 26 janvier, 1973.

CASADO RAIGON, R.: "Las obligaciones erga omnes en el Derecho Internacional contemporáneo», La Ley, n. ${ }^{\circ} 1120$, año IV, Madrid 29 de enero de 1985.

Castaño, L.: La libertad de pensamiento y de imprenta, Universidad Nacional Autónoma de México, México 1976.

COHEN-JONATHAN, G.: «La reconnaissance par la France du Droit de Recours individual devant la Commission Européenne des Droits de l'Homme», en Annuaire Français de Droit International, 1981.

COMTE, F.: «La aplicación del Convenio Europeo de Derechos Humanos en el orden juridico interno", Revista de la Comisión Internacional de Juristas, vol. IV, 1962.

Cossio DIAZ, J. R.: Estado Social y derechos de prestación, CEC, Madrid 1989.

CUADRA-SALCEDO, T.: El recurso de amparo y los derechos fundamentales en las relaciones entre particulares. Alianza Editorial, Madrid 1981.

DecauX, E.: "La mise en vigueur du Pacte international relatif aux droits civils et politiques", Revue Générale de Droit International Public (Paris), vol. 84, n. ${ }^{\circ}$ 2, 1980.

Drzemczewski, A.: «La Convention Européenne des Droits de l'Homme et les rapports entre particuliers», Cahiers de Droit Européen, 16, año 1980. 
DrzemczeWski, A.: The domestic status of the European Convention on Human Rights: new dimensions. Legal Issues of the European Integration, 1977.

-: «The Domestic Application of the European Human Rights Convention as European Community Law", The International and Comparative Law Quartely, 1981.

-: «The European Human Rights Convention and relations between private parties", Netherlands International Law Review, vol. XXVI, issue 2, 1979.

-: European Human Rights Convention in Domestic Law. A Comparative study. Clarendon Press, Oxford 1983.

Embid Irujo, A.: «El Tribunal Constitucional y la protección de las libertades públicas en el ámbito privado", Dirección General de lo Contencioso del Estado, El Tribunal Constitucional, vol. I, Madrid, Instituto de Estudios Fiscales, 1981.

Emerson, T. I.; Haber, D., y Dorsen, N.: Political and Civil Rights in the United States, 2 vols., Boston, Little Brown, 1967.

ERMACORA, F.: “L'ácces aux mécanismes jurisdictionnels de protection des personnes privées dans la Convention Européenne des Droits de I'Homme", Revue des Droits de l'Homme, 1973, Colloque de Grenoble, 25 et 26 janvier de 1973.

EVANS, V.: The practice of European countries where direct effect is given to the European Convention on Human Rights in International law. Proceedings of the Colloqy about the ECHR, Atenas, septiembre 1978; Conseil de l'Europe, septiembre 1979.

FAWCETT, J. E. S.: «Human Rights and domestic jurisdiction», The international protection of Human Rights, London 1976.

Fernandez-Miranda Campoamor, C.: «La discriminación por razón de sexo. Algunos problemas derivados de una línea jurisprudencial vacilante», Revista de Derecho Político, n. . 26, Madrid 1988.

Fernández Sola, N.: Derechos civiles y políticos de los extranjeros en España dentro del marco de la Convención Europea de Derechos Humanos. Tesina mimografiada, Universidad de Zaragoza, febrero de 1985. 
Flathman, R.: The Practice of Rights. London, Cambridge University Press, 1976.

Franchini, F.: «Efficacia delle norme costituzionali», en Archivo Penale, vol. VI, tomo I, Milano 1950.

FroweIN, J. A.: La notion de victime dans la Convention Européenne des Droits de l'Homme, en Studi in onore di Giuseppe Sperduti, Dolt, A. Giuffré Editore, Milano 1984.

Ganshof Van der Meersch, W. J.: «Aspects de la mise en oeuvre d'une sauvegarde collective des droits de I'homme en Droit International. La Convention Europeénne», Mélanges Fernand Dehousse, Ed. Labor, Bruselas 1979.

-: Does the Convention have the force of "ordre public» in municipal law? Human Rights in national and international law. The proceeding of the 2nd International Conference on the European Convention of Human Rights held in Vienna, 18-20 october 1965, Manchester University Press; Dobbs Ferry, N.Y. Oceana Publishing, 1968.

-: Quelques réflexions sur les mesures de nature à accompagner la fusion de la Commission et de la Cour, II Séminaire de Droit International et de Droit Européen, Neuchâtel, marzo 1986.

-: "Reliance, in the case-law of the European Court of Human Rights, on the Domestic law of the States", HRLJ, vol. I, 1980.

-: La Convention Européenne des Droits de l'Homme, à-t-elle, dans le cadre du droit interne, une valeur d'ordre public. Actes du II Colloque international sur la Convention Européenne des Droits de l'Homme, Vienne 1965.

GARCIA MACHO, R.: Las aporias de los derechos fundamentales y el derecho a una vivienda, IEAl, Madrid 1982.

Garcia MuRCIA, J.: "Derechos fundamentales y negociación colectiva; una aproximación desde la jurisprudencia constitucional», Revista de Estudios Políticos, n. $^{\circ} 87,1988$. 
Garcia Torres, J., y Jiménez Blanco, A.: Derechos fundamentales y relaciones entre particulares. La Drittwirkung en la Jurisprudencia Constitucional. Cuadernos Civitas, Madrid 1986.

Gerbino, M.: «Considerazioni.sugli effetti delle sentenze delia Corte Europea dei diritti dell'uomo», 3, Rivista di Diritto Europeo, 1963.

GiARDinA, A.: "Le mise en oeuvre au niveau national des arrêts des décisions internationaux», RCADI, 1979, vol. IV, n. ${ }^{\circ} 165$.

Golsong, H.: Quelques réflexions à propós du pouvoir de la Cour Européenne des Droits de l'Homme d'accorder una satisfaction équitable (article 50 de la Convention Européenne des Droits de l'Homme). Mélange René Cassin, vol. I, Paris 1969.

-: L'effect direct, aussi que le rang en droit interne, des normes de la Convention Européenne des Droits de l'Homme et des décisions prises par les organes institués par celle-ci. En el libro "Les recours des individus devant les instances nationales en cas de violation, du Droit européen», del Institut d'Études Européennes, Bruselas 1978.

-: "The European Convention on Human Rights before domestic courts», The British Yearbook of International Law, vol. 38, 1962.

GonzÁlez Casanova, J. A.: «El derecho a la libre expresión y a la información", en Cuadernos para el Diálogo, n. ${ }^{\circ}$ extraordinario XI, diciembre 1968.

GRAY, C. D.: Remedies for individuals under the European Convention on Human Rights. HRLY, vol. VI, n. ${ }^{\circ} 3,1981$.

JAÉN VALLEJo, M.: «El principio de igualdad en la aplicación de la ley por los órganos jurisdiccionales en la jurisprudencia del Tribunal Constitucional», en Boletín del llustre Colegio de Abogados de Madrid. Revista Jurídica General, n. ${ }^{\circ}$ 2, marzo-abril 1987.

KISs, A. Ch.: L'État Moderne et le Droit International. Rapport général du Colloque Internationale sur la conception du Droit et de l'État dans l'ere de revindication de la dignité de la personne humaine. Rome, 29 à 31 octobre, 1984.

KovaR, R.: «L'efficacité des mécanismes jurisdictionnels de protection des personnes privées dans le cadre européen", Revue.de Droits de l'Homme, vol. 6, 1973. 
LANDY, E. A.: The effectiveness of international supervision: three decades of ILO experience. Dobbs Ferry, N.Y., Oceana, 1966.

LANNUNG, H.: Quelques observations sur le problème de la mise en oeuvre des Droits de l'Homme dans le cadre européen. Paris-Dalloz, 1961.

LEARY, V.: «The Right of the Individual to Know and Act upon His Rights and Duties: Monitoring Groups and the Helsinki Final Act", Vanderbilt Journal of Transnational Law, vol. 13, 1980.

LIÑAN Nogueras, D.: «Efectos de las sentencias del Tribunal Europeo de Derechos Humanos y Derecho Español», REDI, vol. XXXII, n. ${ }^{\circ} 2,1985$.

-: El detenido en el Convenio Europeo de los Derechos Humanos. Secretariado de Publicaciones de la Universidad de Granada, 1980.

MAGNNE, Y.: «Les expériences personnelles de la Convention: L'expérience d'un cas avec les organs de la Convention, Revue des Droits de l'Homme, n. ${ }^{\circ} 3,1982$.

MANUAL DE ACCION: Cómo llevar a la práctica la igualdad entre los sexos (editado por la Comisión de las Comunidades Europeas). Instituto de la Mujer, Ministerio de Asuntos Sociales, Madrid 1990.

MARKET, F.: Du conflict entre l'ordre juridique interne et l'ordre public international, Journal des Tribunaux, 1974.

MARTÍNEZ EMPERADOR, R.: «Despidos discriminatorios y recurso de amparo constitucional", Revista Española del Derecho del Trabajo, n. ${ }^{10}$, 1982.

MERTENS, P.: Origines et fondements d'un droit de recours interne en cas de violation d'une norme de Droit International. Les recours des individus devant les instances nationales en cas de violation du droit européen. Colloque organisé les 24 et 25 avril 1975, Bruxelles, Lancier, 1978.

-: Le droit de recours effectif devant les instances nationales en cas de violation d'un droit de l'homme (dissertation), Institut d'Études Européennes, Univesité Libre de Bruxelles, 1973.

Modinos, P.: «Effects and Repercussions of the European Convention on Rights», International and Comparative Law Quarterly, 1962.

Muller-Rappard, E.: Le droit d'action en vertú des dispositions de la Convention Européenne des Droits de l'Homme. La protection internationale des droits de l'homme, Bruxelles, Éditions de l'Université de Bruxelles, 1976. 
NoWAK, M.: «The Effectiveness of the International Convention on Civil and Political Rights-Stocktaking after the First Eleven Sessions of the UN Human Rights Committee", Human Rights Law Journal (Kehl am Rhein), vol. 1, 1980.

Ortega Díz-Ambrona, J. A.: "Derechos fundamentales y realidad jurídica vivida", en Actas del I Congreso de Filosofía del Derecho, Madrid 1964.

Palmieri, G. M.: L'abuso del diritto di ricorso individuale dinanzialla Commissione Europea dei Diritto dell'Uomo. Studi in onore di Giuseppe Sperdutti D. A. Giuffré Editore, Milano 1984.

«L'esperienza italiana in tema di ricorsi individuali alla Commissione Europea dei Diritto dell'Uomo», Rivista di Diritto Internazionale, 1980.

Parejo Alfonso, L.: «El contenido de los derechos fundamentales en la jurisprudencia constitucional a propósito de la sentencia del Tribunal Constitucional de 8 de abril de 1981", Revista de Derecho Constitucional, n. ${ }^{\circ} 3,1981$.

Pelloux, R.: «L'accès aux mécanismes jurisdictionnels de protection des personnes privées dans le cadre européen. III Colloque de Grenoble, 25 et 26 janvier», Revue des Droits de l'Homme, 1973.

Peinado LoPez, A.: "Discriminación de la mujer en el mercado de trabajo español: Un análisis empírico de la discriminación", en REDC, $\mathrm{n}$. 28, 1987.

QuAdRa-Salcedo, T.: El recurso de amparo y los derechos fundamentales en las relaciones entre particulares, Cuadernos Civitas, Madrid 1981.

RESs, M. G.: Effect des arrêts de la Cour Européenne des Droits de l'Homme droit interne et pour les tribunaux nationaux. Conseil de l'Europe Act. Colloque Internacional sur la Convention Européenne des Droits de l'Homme. Frankfurt, 9-12 avril 1980, Paris, Pedone, 1982.

RobertSon, A. H.: The relationship between the European Convention on Human Rights and internal law in general. European Criminal Law, Colloques Européens Bruxelles, Press Universitaires de Bruxelles, 1970.

-: Agreement relating to persons participating in protection of the Human Rights. Miscelanea W. J. Gaushoff van der Meersch, V. Bruxelles 1972.

-: Applying and effecting compliance with decisions reference to the European Convention on Human Rights. The effectiveness of national decisions. Papers of a conference of the American Society International Law, and the proceeding of the conference, edited by Stephen Leyden, A. W. Sijthoff; Dobbs Ferry, N. Y., Oceana. 
Robertson, A. H.: L'effectivité et efficacité de la garantie des droits de l'homme inscrits dans la Convention Européenne des Droits de l'Homme. Conseil de l'Europe. Actes du quatrième Colloque, Rome, nov. 75.

RodRIGUeZ PIÑERo, M.: «El principio de igualdad y las relaciones laborales», en Revista de Política Social, n. ${ }^{\circ} 121$, enero-mayo, 1979.

Rodriguez Piñero, M., y FernÁndez López, M. F.: Igualdad y discriminación, Tecnos, Madrid 1986.

RogeL, C.: Bienes de la personalidad, derechos fundamentales y libertades. Studia Albornotiana, Publicaciones del Real Colegio de España, BoIonia 1985.

SAN Jose, B.: Democracia e igualdad de derechos laborales de la mujer, Instituto de la Mujer, Ministerio de Asuntos Sociales, 2. ${ }^{a}$ ed., Madrid 1990.

SCOBLE, H., y WISEBERG, L.: “Amnesty International: evaluating effectiveness in the Human Rights arena. There is a compelling need for protective associations to monitor governmental repressión", Intellect (New York), september-october 1976.

SCHACHTER, O.: «The Obligation of the Parties to Give Effect to the Covenant on Civil and Political Rights», American Journal of International Law (Washington, D.C.), vol. 73, 1979.

SCHREUER, Ch.: «The impact of international institutions on the protection of human rights in domestic courts», Israel Yearbook on Human Rights (Tel Aviv), vol. 4, 1974.

SCHWELB, E.: "Complaints by individuals to the Commission of Human Rights: twenty-five years of uphill struggle (1947-1971)», in C. Boasson and $\mathrm{N}$. Nurock (Eds.), The changing international community, The Hague, Mouton, 1973.

SORENSEN, M.: Obligations d'un état partie à un traité sur le plan de son droit interne. Les droits internationaux. Actes du ${ }^{\circ}{ }^{\circ}$ Colloque International sur la Convention Européenne des Droits de l'Homme, Vienne, 18-20 oct. 1965, Bruxelles, Press. Universitaires, 1968.

Suy, E.: L'individu devant la Cour Européenne des Droits de l'Homme. Internationales Colloquim üben Menscheurechte Colloque International sur les Droits de l'Homme. Berlin, 1966, Deutsche Gesellschaft für die Vneinten Nationel.

VELU, J.: Les effects directs des instruments internationaux en matière de Droits de l'Homme. Société belge de Droit International: Réunion 
d'étude à Wilnijk 7 nov. 1980. L'effect direct en Droit belge des traités internationaux relatifs en particulier. Bruxelles, Bruyland; Ed. de l'Univ. de Bruxelles, 1981.

Velu, J.: Les voices de droit devant aux individus, devant les instances nationales en cas de violation de la Convention Européenne des Droits de l'Homme. Le recours des individus devant les instances nationales en cas de violation du Droit Européen. Institut d'Études Européennes. Université Libre de Bruxelles, 1978.

-: Responsabilités decoulant de la mise en oeuvre de la Convention Européenne des Droits de l'Homme. - Les responsabilités incombrant, aux Etats Parties à la Convention-. Cons'eil de l'Europe, doc. H/COU (85) 3, juillet 1985.

-: "Les effects directs des instruments internationaux en matière de droits de I'homme", Revue Belge de Droit International (Brussels), vol. 15, 1980.

WAelbroeck, M., y Velu, J.: Les recours des individus devant les instances nationales en cas de violation du droit européen. Maison F. Larcier, Bruxelles 1978.

ZaNGHI, Cl.: L'effectivité et l'efficacité de la garantie des Droits de l'Homme inscrits dans la Convention Européenne des Droits de l'Homme, en Actes du IV ${ }^{\text {ème }}$ Colloques sur la Convention Européenne des Droits de l'Homme, Conseil de l'Europe, Rome, nov. 75.

ZOUREK, J.: Le respect des droits de l'homme et des libertés fondamentaux constitutif une affaire interne de l'Etat?, en Estudios de Derecho Internacional. Homenaje al Profesor Miaja de la Muela, Ed. Tecnos, Madrid 1979. 